\title{
THOMAS HOBBES, DIODORUS SICULUS, AND EARLY
}

\section{HUMANITY}

\section{Introduction: Hobbes, Thucydides, and Diodorus}

It is uncontroversial to say that Thomas Hobbes had a wide-ranging engagement with classical texts over his long career. Aside from his translation of the Homeric epics done late in life, perhaps his most noteworthy activity as a classicist was his 1629 translation of Thucydides' magnum opus of early historiography, written in the late fifth century BC. ${ }^{1}$ In fact, this translation of Thucydides, titled Eight Bookes of the Peloponesian Warres, was the first output to which Hobbes appended his name, so it plays an important role in understanding the evolution of Hobbes's intellectual oeuvre more broadly ${ }^{2}$ Strauss even thought that the act of translating Thucydides was "heralding his philosophic life-work," hence laid the foundations for everything that Hobbes did afterwards. ${ }^{3}$ Reflecting

\footnotetext{
${ }^{1}$ On Hobbes as a translator of classical texts, see the Clarendon edition of his Homeric translations: Eric Nelson, ed., Thomas Hobbes: Translations of Homer (Oxford: Clarendon Press, 2008).

${ }^{2}$ See Christopher N. Warren, "Hobbes's Thucydides and the Colonial Law of Nations," The Seventeenth Century 24 (2009): 260-286.

${ }^{3}$ Leo Strauss, The Political Philosophy of Hobbes: Its Basis and Its Genesis (Oxford: Clarendon, 1936), 44. It is worth noting, too, that Hobbes jocularly compared to himself to Thucydides in offering advice to his patron, Charles Cavendish, in his 1638 correspondence with him: Noel Malcolm, ed., Thomas Hobbes, The Correspondence, vol I.: 1622-1659 (Oxford: Clarendon Press, 1994), 52-53 (letter 28): "Which I shall leaue to your choyce to
} 
autobiographically towards the end of his life, Hobbes wrote that he found reading Thucydides' history to be more edifying than any other classical text because it taught him how ineffective was democracy as a mode of political organisation, and how preferable was the rule of one man.

And then I turn to our Histories, to Greek, and to Latin ones; I also frequently read Poems. Horace, Vergil, and Homer I came to know, Euripides, Sophocles, Plautus, Aristophanes, and more, and many Writers of Histories; but Thucydides pleased me above the rest. He taught me how foolish (inepta) Democracy is, and how much wiser one Man is than an Assembly. I brought it about that this Writer would speak to the English, so that they would shun the rhetoricians they were about to consult. ${ }^{4}$

Evidently, in Hobbes's eyes, fundamental lessons about contemporary life and institutions could be drawn from classical wisdom, and indeed positioning in contemporary debates could be signalled through reference to classical "banners." Even the specific lesson adduced here, about shunning rhetoricians, is a classical trope well-known in critiques of Athenian

weigh as the humble aduice of a servant, or to laugh at it, or call me foole or Thucidides for my presumption."

${ }^{4}$ Thomas Hobbes, Vita carmine expressa (quotation from $O L$ I.88, translated by Karl Maurer). Essentially the same thought is found in Hobbes's prose autobiography of 1681 . ${ }^{5}$ Cf. Patricia Springborg, "The Enlightenment of Thomas Hobbes," British Journal for the History of Philosophy 12 (2004): 516: “...while positions in [contemporary] debates were often flagged by banners of the classical philosophical schools, their immediacy related to preoccupations of the day." 
democracy, referring to the ingrained viewpoint that clever oratory had the capacity to subvert the democratic process. ${ }^{6}$

Rightly, this deep, specialised link between Hobbes and Thucydides has been strongly emphasised in scholarship. ${ }^{7}$ Often, as a result, it is thought that Thucydides exerted a predominant sway over Hobbes's political philosophy in toto: for example, in Hobbes's translation of Thucydides there are perhaps prefigurations of ideas to be fleshed out more fully in later works like Leviathan, or there is direct sympathy with Thucydides' views on

${ }^{6}$ A notable example of this trope is to be found in Thucydides, in Cleon's speech in the Mytilenian Debate: Thucydides 3.37-40 — this is a good example of "the rhetoric of antirhetoric," i.e. a condemnation of rhetorical style that is itself highly stylised: see Jon Hesk, Deception and Democracy in Athens (Cambridge: CUP, 2000): 248-58. On Hobbes's wider critique of Athenian democracy, see: Laurie M. Johnson, Thucydides, Hobbes, and the Interpretation of Realism (Ithaca, NY: Cornell University Press, 1993), 152-4.

${ }^{7}$ Good recent coverage includes: Warren, "Thucydides and the Colonial Law of Nations," 260-86; James Jan Sullivan, "Hobbes and His Contemporaries," in A Handbook to the Reception of Thucydides, ed. Christine Lee and Neville Morley (Oxford: Wiley-Blackwell, 2015), 241-60; Kinch Hoekstra, "Hobbes and Thucydides," in The Oxford Handbook of Hobbes, ed. A.P. Martinich and K. Hoekstra (Oxford: OUP, 2016), 547-74. More recently still, Timothy Raylor, Philosophy, Rhetoric, and Thomas Hobbes (Oxford: OUP, 2018), 6593. There is a full list of works discussing Thucydidean influence on Hobbes at: Peter J. Ahrensdorf, "The Fear of Death and the Longing for Immortality: Hobbes and Thucydides on Human Nature and the Problem of Anarchy," American Political Science Review 94 (2000): 579 n.6. 
human nature. ${ }^{8}$ Moreover, one could easily see the appeal—for Hobbes, for readers of his translation, and for the general reception of the ideas that stemmed from it — of Thucydidean political reflections against the backdrop of Charles I's crisis-wracked reign (1625-1649), popular upheaval and civil war (1642-1651), and indeed the broader institutional changes of seventeenth-century England. ${ }^{9}$ We can comfortably place such readings in the longer-term phenomenon that is the reception of Thucydides' text, which has been an adaptable cultural phenomenon over the centuries, open to dehistoricised interpretations and to relocation into new contexts. ${ }^{10}$ On the other hand, it is also important to bear in mind that often we see

${ }^{8}$ See inter alia: George Klosko and Daryl Rice, "Thucydides and Hobbes's State of Nature," History of Political Thought 6 (1985): 405-9; Clifford W. Brown Jr., "Thucydides, Hobbes, and the Derivation of Anarchy," History of Political Thought 8 (1987), 33-62; Ahrensdorf, "The Fear of Death," 579-593. See also: Gregory Crane, Thucydides and the Ancient Simplicity: The Limits of Political Realism (Berkeley, CA: University of California Press, 1998), 62, adducing the clear link between Thucydides' and Hobbes's understandings of human motivations, at I.76 and Leviathan XIII [60-63] respectively. For generally on Hobbes' ideas and their relation to Thucydides, see Johnson, Thucydides, Hobbes, and the Interpretation of Realism.

${ }^{9}$ Cf. Jonathan Scott, "The Peace of Silence: Thucydides and the English Civil War," in Hobbes and History, ed. G.A.J. Rogers and Tom Sorell (London: Routledge, 2000), 112-36; Luca Iori, Thucydides Anglicus: Gli Eight Bookes di Thomas Hobbes e la ricezione inglese delle Storie di Tucidide (1450-1642) (Rome: Edizioni di Storia e Letteratura, 2015), 215-248. ${ }^{10}$ See Christine Lee and Neville Morley, "Introduction: Reading Thucydides," in $A$ Handbook to the Reception of Thucydides, ed. Christine Lee and Neville Morley (Oxford: Wiley-Blackwell, 2015), 1-10, esp. 2. 
Thucydides where we want to see him, on account of the inescapability of his intellectual legacy as well as the assumptions of his exemplary dominance that reflect our own, modern construction and acceptance of his authority. ${ }^{11}$

Framing the question of classical influences on Hobbes's engagement with his contemporary world from a rather different and overlooked angle, this article investigates his relationship with a historian virtually regarded as Thucydides' antithesis, namely Diodorus Siculus. Diodorus' historical work, written in the first century BC, was a forty-book "universal history" - notionally, a history of all peoples of the world under a single conspectus, perhaps the fullest attempt at such in antiquity ${ }^{12}$ - that was suggestively titled the

\footnotetext{
${ }^{11}$ See the salutary remarks at: Katherine Harloe and Neville Morley, "Introduction: The modern reception of Thucydides," in Thucydides and the Modern World: Reception,
} Reinterpretation and Influence from the Renaissance to the Present, ed. Katherine Harloe and Neville Morley (Cambridge: CUP, 2012), 19: “The authority of Thucydides' work - and it should be emphasised that this frequently means the idea of Thucydides' work... is refigured according to the prevailing discourse of knowledge... [T]hese different means of constituting Thucydides' authority are not only a reflection of changing conceptions of science, historiography and other forms of intellectual activity; the idea of Thucydides is deployed deliberately as a means of intervening in debates about what history or political theory should be and how it should be done."

${ }^{12}$ Cf. Charles E. Muntz, Diodorus Siculus and the World of the Late Roman Republic (New York: OUP, 2017), 27: “[N]one of Diodorus’ predecessors could claim such an expansive reach, although several of them were important innovators in the development of this universal historiography." For the genre of universal history in antiquity, see: Peter Liddel 
Bibliotheke Historike ("Historical Library"). It is very different to the highly rationalistic and individualistic work of Thucydides, revealing a deep interest in moral didacticism, particularly stressing the principle that mild behaviour and doing good to others have positive outcomes across all known human history. ${ }^{13}$ The work is itself a kind of encyclopaedic storehouse of history-writing, gathering together a cosmopolitan body of material and lessons drawn from different ages, cultures, individuals, and genres, rather than a univocal or revolutionising contribution to the historiographical genre per se-though this is not to deny Diodorus any originality, editorial voice, or indeed significance in the longer duration of (ancient) European intellectual history. ${ }^{14}$ Probably because of the Bibliotheke's collective,

and Andrew Fear, ed., Historiae Mundi: Studies in Universal Historiography (London: Duckworth, 2010).

${ }^{13}$ On moralising in Diodorus, see principally: Lisa Irene Hau, Moral History from Herodotus to Diodorus Siculus (Edinburgh: Edinburgh University Press, 2016), 73-123.

${ }^{14}$ At I.1.3 of the Bibliotheke, Diodorus himself says that writers of universal histories provide a koinon chrēmatistērion, a "common storehouse" (or, perhaps "common counting-house," the metaphor being one of collecting wealth - this analogy expresses that the collected historical material has high "value"), for knowledge of the affairs of all peoples in the inhabited world. On the "encyclopaedic" and "cosmopolitan" nature of Diodorus' work, see: Yun Lee Too, The Idea of the Library in the Ancient World (Oxford: OUP, 2010), 143-169; Jason König and Greg Woolf, "Encyclopaedism in the Roman Empire," in Encyclopaedism from Antiquity to the Renaissance, ed. Jason König and Greg Woolf (Cambridge: CUP,

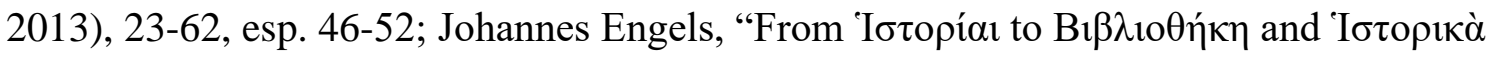

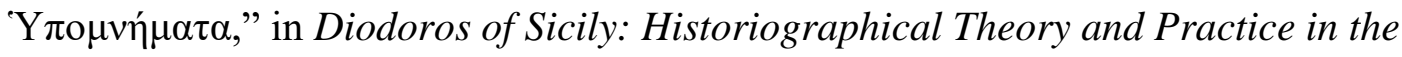


compilatory quality, Diodorus was esteemed by Hobbes as "the greatest antiquary perhaps that ever was," and he seems to have utilised and explicitly valued readings of Diodorus at various junctures across his oeuvre. ${ }^{15}$ How intellectually formative was Hobbes's reading of Diodorus remains to be seen, but such high opinion certainly warrants further investigation, not least for the potential to offer a view of Hobbes's classicism not totally dominated by the long shadow of Thucydides. ${ }^{16}$

Further study is also warranted by the fact that Hobbes's high opinion of Diodorus contrasts strikingly with the latter's reception in more recent modernity, especially since the nineteenth century. ${ }^{17}$ The Bibliotheke, deemed to be less original and less transformative than

Bibliotheke, ed. Lisa Irene Hau, Alexander Meeus, and Brian Sheridan (Leuven: Peeters, 2018), 131-147.

15 Thomas Hobbes, Behemoth, ed. Paul Seaward (Oxford: Clarendon, 2010), p. 225 (II.91). Cf. the description of Diodorus as veteris historiae transcriptor, "transcriber of ancient histories" at De homine I.1, where he is the source of accounts of cosmogony; and as "a very faithful writer" in Ch. 1 of the Decameron Physiologicum (EW VII.73), where he is a source on the origins of natural philosophy.

${ }^{16}$ The only discussion I have seen about the potential of Hobbes' estimation of Diodorus to challenge Thucydides' perceived dominance in Hobbesian thought is a brief one, at: Robert Kraynak, History and Modernity in the Thought of Thomas Hobbes (Ithaca, NY: Cornell University Press, 1990), 23 n.15. Kraynak's discussion on this point is scrutinised in section 4, below.

${ }^{17}$ See: Peter Green, ed., Diodorus Siculus, Books 11-12.37.1: Greek History, 480 - 431 BCthe Alternative Version (Austin, TX: University of Texas Press, 2006), 31-34. One also gets the sense of a vibrant pre-modern reception of Diodorus from: Benjamin Farrington, 
the work of other ancient historiographers, has until very recent decades been cast as a “mindless," "slavish," “derivative," and "incompetent" work; Diodorus himself has been called no less than "this most miserable of all writers," "one of the worst historians" to survive from all antiquity, and even a "stupid, credulous, prosing old ass."18 This is owing largely to the dominance of Quellenforschung and Quellenkritik as historical methodologies over the nineteenth and twentieth centuries, and through a positivistic model Diodorus scored rather poorly on the grounds of reliability and originality: he was judged to have copied everything meaningful from his earlier sources, most of which are now lost, and even this he did sloppily; and he did not intrude authorially into his own text in any significant manner. ${ }^{19}$

Diodorus Siculus: Universal Historian (Swansea: University of Wales Press Board, 1937), 67, 9, 35-6 n. 1.

${ }^{18}$ For the first two slurs, see: Jane Hornblower, Hieronymus of Cardia (Oxford: OUP, 1981), 19, citing Niebuhr and Mommsen. Lord MacAulay is the one who called Diodorus an "ass," but also added immediately afterwards “...yet I heartily wish that we had a good deal more of him"; for the full quotation, with reference, see Iris Sulimani, Diodorus' Mythistory and the Pagan Mission: Historiography and Culture-Heroes in the First Pentad of the Bibliotheke (Leiden: Brill, 2011), xiii.

${ }^{19}$ For recent surveys of Diodorus' reception in modern scholarship, see: Sulimani, Diodorus' Mythistory, 3-10; Muntz, Diodorus and the Late Roman Republic, 1-26; Lisa Irene Hau, Alexander Meeus, and Brian Sheridan, "Introduction," in Diodoros of Sicily: Historiographical Theory and Practice in the Bibliotheke, ed. Lisa Irene Hau, Alexander Meeus, and Brian Sheridan (Leuven: Peeters, 2018), 3-12. Remedying the illogic of many positivistic interpretations, and generating new reassessments of Diodorus' capacity as a 
This perception of Diodorus as an incompetent and uncritical epitomator has begun to change in recent decades, and the future looks set for a millennial shift in scholarly assessments of Diodorus' work. In this vein, Hobbes's laudatory viewpoint on Diodorus, coming as early as the seventeenth-century, while striking the modern reader as unusual and surprising, perhaps even dissonant, is certainly ripe for investigation-especially since there is no existent study of Hobbes's reading of Diodorus. ${ }^{20}$

In light of these aims, this article consists of three central parts. Firstly, this article will contextualise Diodorus Siculus' reception in England, beginning with the first English translation of the Bibliotheke by John Skelton in the late fifteenth century, as a necessary underpinning for situating Hobbes's reading of the historian and his work as well as for understanding Diodorus' work in a pre-Quellenforschung world. Then, this investigation will proceed to an examination of two Hobbesian works, namely the De homine ("On Man") of 1658 and the later work Behemoth, perhaps written in the late $1660 \mathrm{~s}^{21}$ These two works

historian, is much indebted to the work of: Kenneth S. Sacks, Diodorus Siculus and the First Century (Princeton, NJ: Princeton University Press, 1990).

${ }^{20}$ Brief discussions of Hobbes and Diodorus can be found at e.g.: Kraynak, History and Modernity, 7-31 (occasional references throughout this chapter); Patricia Springborg, "Hobbes, Heresy, and the Historia Ecclesiastica," Journal of the History of Ideas 55 (1994): 553-571. But it is worth noting that scholars have often overlooked Diodorus' place in Hobbes's classical reading materials: NB. his absence from the exploration of "Hobbes's humanist studies" at: Quentin Skinner, Reason and Rhetoric in the Philosophy of Hobbes (Cambridge: CUP, 1996), 230-38.

${ }^{21}$ Dating Behemoth in particular is a complex problem, on which see: Paul Seaward, ed., Thomas Hobbes: Behemoth (Oxford: Clarendon Press, 2010), 6-10. 
display an evident indebtedness to Diodorus, and although they are framed differently, their lines of influence show a subversive, oppositional intellectual agenda driving the use of the Diodoran text, the target of which is contemporary theological and political structures. Here, Diodorus' narratives of early human societies - the Egyptians, Assyrians, Ethiopians, and others, notably before the advent of classical Greece and Rome-in the first five books of the Bibliotheke are shown to be the focus of Hobbes's attention for his subversive agenda against organised religion in the English state. Finally, this article will reflect on ideologies underpinning Hobbes's reception of Diodorus' work and consider why early humanity, as presented in the first pentad of Diodorus' Bibliotheke, proved to be such a fertile thinkingground for Hobbes's reflection on contemporary issues and questions.

\section{Diodorus in early modern England, from Skelton to Hobbes}

A complete copy of Diodorus' Bibliotheke Historike in forty books was rumoured to survive intact at the Ottoman conquest of Constantinople in 1453 - where it had had its own long tradition of reading, even among the very highest levels of society, judging by a copy thought to have Niketas Choniates' marginal notes_-but it probably did not survive the Crusaders' sacking of the city in 1204 , and in the west it was virtually unknown until a good deal later in the early fifteenth century. ${ }^{22}$ Although it seems to have been known to some figures in the

${ }^{22}$ On Lascaris and the rumour, see L.D. Reynolds and N.G. Wilson, Scribes and Scholars: A Guide to the Transmission of Greek and Latin Literature (Oxford: Clarendon Press, 1991), 72; John Monfasani, “Diodorus Siculus,” in Catalogus Translationum et Commentariorum: Medieval and Renaissance Latin Translations and Commentaries: Annotated Lists and Guides, vol. 11, ed. Greti Dinkova-Bruun et al. (Toronto: Pontifical Institute of Medieval Studies, 2016), 66-67. On Diodorus among Niketas Choniates and the Constaninopolitan 
first decade of the fifteenth century, particularly in Florence, ${ }^{23}$ the Greek manuscript of books 1-5 of the Bibliotheke, the first pentad of Diodorus' work, was properly "rediscovered" by Poggio Bracciolini and translated (probably with the assistance of George of Trebizond) into Latin in 1449 , with a dedication to Pope Nicholas V. ${ }^{24}$ Diodorus seems to have been very

elite, see: Anthony Kaldellis, Byzantine Readings of Ancient Historians: Texts in translations with introductions and notes (London: Routledge, 2015), 8-97. On later manuscript traditions and translations of Diodorus' work, which are not necessarily a proxy for gauging access and circulation but perhaps nonetheless convey continuity of perceived importance (or at least taste), see Monfasani, "Diodorus Siculus," 61-152.

${ }^{23}$ It was been suggested that the Bibliotheke was one of the first Greek texts to be read in Florence, and perhaps the very first Greek historiographical work studied there; there are certainly references to Diodorus' work as early as 1405/6, on which see: Dorothy M. Robathan, "Diodorus Siculus in the Italian Renaissance," Classical Philology 27 (1932): 84; William Connell, "The Eternity of the World and Renaissance Historical Thought," California Italian Studies 2 (2011), 13. Much later, we know e.g. that Macchiavelli read and used Diodorus' work, the first pentad in the Discorsi (there is a direct reference to Diodorus at Discorsi II.5) and other books in smaller works: for arguments that Diodorus books XIXXX underpin certain parts of Machiavelli's Vita di Castruccio Castrucane, for instance, see: John Monfasani, "Machiavelli, Polybius, and Janus Lascaris: the Hexter Thesis Revisited," Italian Studies 71 (2016), 39-48.

${ }^{24}$ On Poggio's Diodorus, see: F.M. Salter and H.L.R. Edwards, ed., The Bibliotheca Historica of Diodorus Siculus, translated by John Skelton, 2 vols (Oxford: Oxford University Press, 1956-7), esp. 2.xx-xxii. For translation assistance from George of Trebizond: John Monfasani, George of Trebizond: A Biography and a Study of his Rhetoric and Logic 
popular in the continental renaissance, with the Bibliotheke becoming a recurrent feature of Renaissance scholarship, particularly on the origins of the universe and the early history of humanity, as recorded in the first pentad of the Bibliotheke. ${ }^{25}$ These interests were to be shared by Hobbes, as we shall see in the next sections. In short, the circulation of Diodorus' work seems to have been quite wide, and the work itself was highly valued and had a tangible impact on early humanistic studies.

This impact was felt extremely early in England, too. William Caxton's prologue to John Trevisa's 1482 Polychronicon shows an indebtedness to the Bibliotheke, in all probability to Poggio's Latin translation. ${ }^{26}$ Poggio's Latin Diodorus was then translated

(Leiden: Brill, 1976), 69-71, with n.7. An accessible digitised copy of Poggio's translation may be consulted via the University of Chicago's Library: Diodorus, Siculus, Bibliotheca historica. Manuscript, Codex Ms 14, Special Collections Research Center, University of Chicago Library [09/03/2020:

https://www.lib.uchicago.edu/e/scrc/findingaids/view.php?eadid=ICU.SPCL.MS14].

${ }^{25}$ In particular see: Nicholas Davidson, "Unbelief and Atheism in Italy, 1500-1700," in Atheism from the Reformation to the Enlightenment, ed. Michael Hunter and David Wootton (Oxford: OUP, 1992), 55-86, esp. 61-63; Connell, “The Eternity of the World,” 1-23, esp. 1314; C. Philipp E. Nothaft, "The Early History of Man and the Uses of Diodorus in Renaissance Scholarship: From Annius of Viterbo to Johannes Boemus," in For the Sake of Learning: Essays in Honor of Anthony Grafton, vol. 2, ed. Ann Blair and Anja-Silvia Goeing (Leiden: Brill, 2016), 711-728.

${ }^{26}$ Stressing the Latinate form of Caxton's borrowing from Diodorus, hence access via Poggio's version, see the discussion at: Daniel Wakelin, Humanism, Reading, and English Literature, 1430-1530 (Oxford: Oxford University Press, 2007), 149-151. Workman had 
wholesale into vernacular (albeit neologistic) English in $c .1487$ by John Skelton, self-styled "poet laureate," who also prefaced his work with a dedication, this time to Henry VII. This dedication is of particular interest because it was in fact a kind of re-dedication, namely a translation of Poggio's dedication to Nicholas V, with the dedicatee replaced and aspects of the translation very freely done. It has been suggested that with this (re)dedication we see how Skelton sought to envision himself as enjoying a position in the Henrician court—wise, intellectual advisor to the ruling power — on the model of Poggio's papal patronage; and in this vein Skelton's translation of the previously unknown text of Diodorus might have been a kind of performative tour de force of intellectualism, advertising a rare humanistic wisdom and ability — not least for "amplifying" the subject matter found in Poggio—in a context in which very few Classical texts had ever been translated into English. ${ }^{27}$ It is worth noting that

suggested that a no longer extant French translation of Poggio's Latin Diodorus was Caxton's source: S.K. Workman, "Versions by Skelton, Caxton, and Berners of a Prologue by Diodorus Siculus," Modern Language Notes 56 (1941): 252-258.

${ }^{27}$ On Skelton's Diodorus, see: Peter Green, John Skelton (London: Longmans, Green \& Co., 1960), 9-10; Malvern Van Wyk Smith, “Africa as Renaissance Grotesque: John Skelton's 1485 Version of Diodorus Siculus," Shakespeare in Southern Africa 13 (2001): 23-31 [09/03/2020: https://journals.co.za/content/iseasosa/13/1/AJA1011582X_161]; Ray Siemens, "Poetic Statesmanship and the Politics of Patronage in the Early Tudor Court: Material Concerns of John Skelton's Early Career as a Critical Context for the Interpretation of The Bowge of Courte," Early Modern Literary Studies 15 (2009-10) [09/03/2020: http://extra.shu.ac.uk/emls/15-1/siemskel.html]; Jane Griffiths, John Skelton and Poetic Authority: Defining the Liberty to Speak (Oxford: Clarendon Press, 2006), 38-55. See also the 
in roughly the same context Skelton had also made translations "Of Tullis Familiars," that is of Cicero's Epistulae ad familiares, which has not survived; ${ }^{28}$ but this parallelism of Cicero and Diodorus preserves something of the importance ascribed to Diodorus right at the start of his reception in early modern England.

Despite competitive self-advertisement for personal gain motivating Skelton's rendition, Diodorus was nonetheless embraced quite broadly in England, particularly the first five books of the Bibliotheke, which were so much the most popular and most published sections of the work that they effectively came to have a distinct tradition of editions and translations..$^{29}$ Over the sixteenth century, we see a considerable impact from Diodorus on shaping discourse on ethnography, geography, and religion in particular. A wealth of examples might be cited. Richard Eden's 1555 English translation of Peter Martyr d'Anghiera's De orbo novo, an account of Spanish conquests in the new world, makes clear that Diodorus was a recurrent source for the (fictitious) outlandish customs of ancient

manuscript-history, text, introduction, and notes for Skelton's translation at: Salter and Edwards, The Bibliotheca Historica.

${ }^{28}$ See David R. Carlson, “John Skelton,” in The Oxford History of Classical Reception in English Literature, vol. 1: 800-1558, ed. Rita Copeland (Oxford: OUP, 2016), 541-559, esp. 544-5 (on Cicero) and 545-7 (on Diodorus).

${ }^{29}$ On manuscript histories of Diodorus' Bibliotheke, see: Pierre Bertrac, Yvonne Vernière, and François Chamoux, ed., Diodore de Sicile: Bibiothèque Historique: Introduction générale, Livre I (Paris: Les Belles Lettres, 1993), lxxvii-clxvi; John Monfasani, “Diodorus Siculus," 61-152. 
peoples, here the "Troglodytes" of Ethiopia in particular. ${ }^{30}$ Such references have an important bearing on the ethnographic construction of native peoples of the new world. ${ }^{31}$ Edmund Spenser, too, seems to have consulted Diodorus on customs of early foreign peoples, judging by direct references in The View of the State of Ireland, where ethnographies of Scythians and Celts give flavour to Spenser's accounts of the sixteenth-century Irish and Diodorus' naming of Ireland as part of Britannia is significantly recalled. ${ }^{32}$ In Spenser's more notable work The Faerie Queene, the cosmogony and the presentation of the legends of Bacchus and Hercules seem to owe something to Diodorus as source material. ${ }^{33}$ Likewise, it has been suggested that Thomas More may have read Diodorus' work, especially given utopian themes and imagery

${ }^{30}$ See: Bruce R. Smith, The Acoustic World of Early Modern England (Chicago, IL: University of Chicago Press, 1999), 327.

${ }^{31}$ Generally, see: Joan-Pau Rubiés, "Ethnography, philosophy and the rise of natural man, 1500-1750," in Encountering Otherness. Diversities and Trans-Cultural Experiences in Early Modern European Culture, ed. Guido Abbattista (Trieste: University of Trieste Press, 2011), 97-127.

${ }^{32}$ See: Philip Schwyzer, Literature, Nationalism and Memory in Early Modern England and Wales (Cambridge: CUP, 2004), 45; Thomas Herron, "Plucking the Perrot: Muiopotmos and Irish Politics," in Edmund Spenser: New and Renewed Directions, ed. J.B. Lethridge (Madison, WI: Fairleigh Dickinson University Press, 2006), 88; Thomas Ward, “Spenser’s Irish Hubbub,” ELH 81 (2014): 757-786, esp. 766-8.

${ }^{33}$ See: Blossom Feinstein, "The Faerie Queene and Cosmogonies of the Near East," Journal of the History of Ideas 29 (1968): 531-550; John Michael Archer, Old Worlds: Egypt, Southwest Asia, India, and Russia in Early Modern English Writing (Stanford, CA: Stanford University Press, 2001), 52-53. 
in some of the narratives he includes in the early books, such as the summary of Iambulus' Islands of the Sun in book two of the Bibliotheke. ${ }^{34}$ Even Henry VIII owned a translation of Diodorus in his Westminster Palace library, judging by his autograph monogram on the title page of the surviving manuscript. ${ }^{35}$

Progressing in time, sixteenth- and seventeenth-century editors and translators were free in their praise for the author, including the European scholars Stephanus and Rhodomann, who provided early critical editions of Diodorus' text. ${ }^{36}$ There is also a negative

${ }^{34}$ See: Farrington, Diodorus Siculus, 25 (also suggesting an influence on Campanella's later La città del Sole); Jürgen Oelkers, "Utopia, state, and democracy," in Education and the State: International Perspectives on a Changing Relationship, ed. Carla Aubry et al. (London: Routledge, 2015), 239-240. On Iambulus, see Diodorus II.55-60.

${ }^{35}$ Hornblower, Hieronymus of Cardia, 19, citing BM General Catalogue no. C45g4 for the Henrician copy. The correct reference is British Library General Reference Collection C.45.g.4, referring to the 1530 publication of a French translation of Diodorus: Claude de Seyssel, L'Histoire Des Successeurs De Alexandre Le Grand, Extraicte De Diodore Sicilien: Et Quelque Peu De Vies Escriptes Par Plutharque, Etc. (Translatee De Grec En Latin, Par Messire Iehan Lascary. Et De Latin En Francoys Par Messire Claude De Seyssel.) [09/03/2020: http://explore.bl.uk/BLVU1:LSCOP-ALL:BLL01000942614]. This volume was from the "Kinges Upper Library" of Westminster Palace: James P. Carley and Ágnes JuhászOrmsby, "Survey of Henrician Humanism," in The Oxford History of Classical Reception in English Literature, vol. 1: 800-1558, ed. Rita Copeland (Oxford: OUP, 2016), 527.

${ }^{36}$ For fuller details, see: Farrington, Diodorus Siculus, 7, 35-36 n.1; Green, Diodorus Siculus, 31-34. Rhodomann's edition, as we shall see, is probably the one that Thomas Hobbes had in the Hardwick library. 
tradition of receiving Diodorus, of course ${ }^{37}$ but his generally high valuation continued to be evident closer to Hobbes's immediate context, as in 1653 an English translation of the first five books of the Bibliotheke - the first since Skelton-was composed by one Henry Cogan, self-styled "gentleman." The frontispiece of Cogan's edition described this pentad as "containing all this is Most Memorable and of greatest Antiquity in the first Ages of the World until the War of Troy." ${ }^{38}$ Indeed, Cogan, in the dedicatory epistle to his patron, wrote that Diodorus' history "hath been of so much repute with the most Learned of all times, as he hath justly acquired a prime place amongst the best Historians of former Ages." It is doubtful that Cogan, or many of his English forebears in reading Diodorus, had actually read or translated from the original Greek, whether owing to access, linguistic (in)ability, or even linguistic (dis)interest. ${ }^{39}$ Regardless of linguistic judgements, however, it is clear to see that the content of Diodorus' work was widely popularised by Hobbes's time, particularly the narratives on the ancient kingdoms of the near east that appear in the first pentad of the Bibliotheke, on which no other extant classical text could provide a comparable level of

\footnotetext{
${ }^{37}$ See: Monfasani, "Diodorus Siculus," 80-81.

${ }^{38}$ Henry Cogan, The History of Diodorus Siculus (London: Printed by John Macock for Giles
} Calvert, 1653). A digitised copy is available at GoogleBooks [10/03/2020:

\section{https://books.google.co.uk/books?id=HnVnAAAAcAAJ]}

${ }^{39}$ Skelton, for instance, had elsewhere spoken disparagingly about the value of the modern man learning ancient Greek, seeing it as inimical, as opposed to Latin, to the proper advancement of the English language (which, in Skelton's time, was still fundamentally a Chaucerian Middle English). See: C.S. Lewis, Oxford History of English Literature, vol. 3: English Literature in the Sixteenth Century Excluding Drama (Oxford: OUP, 1954), 133-143, esp. 134. 
information and detail, nor a similarly broad range of excerptable exempla. John Milton used Diodorean accounts of Egypt and Africa to inform his own visions of such, ${ }^{40}$ for instance, as did John Selden invoke Diodorus' descriptions of Gauls and Druids $;{ }^{41}$ slightly later, John Toland drew on the Euhemeristic narratives of these early books, as well as accounts of Egyptian progress and of the Druids. ${ }^{42}$ George Herbert's poem "Providence," from the 1633 collection On the Temple, also seems to be based on the third book of the Bibliotheke. ${ }^{43}$

This well-established tradition of reading Diodorus in early modern England underpinned and pre-existed Hobbes's engagement, but we should also not downplay the influence stemming from continental humanistic scholarship; indeed, Hobbes's connections and correspondences with European thinkers of the day—-such as Descartes, Mersenne, Gassendi, among others - are well-attested. ${ }^{44}$ It would be my guess that the edition of Diodorus listed in the catalogue of the Hardwick Library (where Hobbes studied under his

${ }^{40}$ See e.g.: William Bridges Hunter, "Egyptology, Milton's," in A Milton Encyclopedia, vol. 9, ed. William Bridges Hunter (London: Associated University Presses, 1983), 15-16. ${ }^{41}$ Reid Barbour, John Selden: Measures of the Holy Commonwealth in Seventeenth-century England (Toronto: University of Toronto Press, 2003), 92-3, 183, 189-90; Collins, Allegiance of Thomas Hobbes, 51.

${ }^{42}$ Justin Champion, The Pillars of Priestcraft Shaken: The Church of England and its Enemies, 1660-1730 (Cambridge: CUP, 1992), 148-9, 155-6; “John Toland, the Druids, and the Politics of Celtic Scholarship,” Irish Historical Studies 32 (2001): 321-342, esp. 335-6. ${ }^{43}$ For more detail, see: Farrington, Diodorus Siculus, 35-36 n.1.

${ }^{44}$ On interpretations of Hobbes alternatively as a "British" and as a "European" intellectual, see: Patricia Springborg, “A Very British Hobbes, or A More European Hobbes?,” British Journal for the History of Philosophy 22 (2014): 368-386. 
patrons the Cavendishes, the earls of Devonshire), which is listed simply as "Diodorus Siculus Gr. Lat. fol.," was the 1604 edition, published in Hanau in Germany, by Laurentius Rhodomanus (a.k.a. Lorenz Rhodomann); this was the first edition of Diodorus to contain the Greek text of all extant books of the Bibliotheke with a new, facing Latin translation in a parallel column, and it remained the standard edition of the Bibliotheke until Peter Wesseling's new edition in $1746 .{ }^{45}$ As well as reinforcing the case for European influence on Hobbes's scholarship, crucially this would mean that Hobbes had access to the full work of Diodorus in the original Greek as well as to textual notes, and so did not, of necessity, solely access content from Diodorus via his contemporaries' references to it and quotations from it - though he may well, of course, have had his interest stimulated by these. ${ }^{46}$ Neither did he, it seems, rely on another scholar's translation of Diodorus' Greek ${ }^{47}$ — which is an important

${ }^{45}$ For the Hardwick Library catalogue, including those entries written by Hobbes himself, see: Richard A. Talaska, ed., The Hardwick Library and Hobbes's Early Intellectual Development (Charlottesville, VA: Philosophy Documentation Center, 2013). Diodorus' work is listed at Chatsworth MS E.1.A, 73-D, no. 673, as "Diodorus Siculus, Gr. Lat. fol." On Rhodomanus’ edition, see: Monfasani, “Diodorus Siculus,” 78-80. ${ }^{46}$ See Patricia Springborg, “Hobbes and Cluverius,” Historical Journal 39 (1996): 10751078; Jeffrey R. Collins, The Allegiance of Thomas Hobbes (Oxford: OUP, 2005), 50-52; Patricia Springborg, “Hobbes’s Historia Ecclesiastica: Introduction: Hobbes, History, Heresy and the Universities," in Historia Ecclesiastica: Critical edition, including text, translation, introduction, commentary and notes, ed. Patricia Springborg, Patricia Stablein, and Paul Wilson (Paris: Honoré Champion Éditeur, 2008), 142-7.

${ }^{47}$ Johann P. Somerville, "Hobbes, Behemoth, Church-State Relations, and Political Obligation," Filozofski vestnik 24 (2003): 206 with n.3. 
point for establishing Hobbes as the likely translator of the sections of Diodorus that he quotes, with a detailed understanding of Greek terminology found there.

\section{Hobbes and Diodorus: subversion and models of classical referentiality}

In moving onto a discussion of subversive agendas underpinning Hobbes's take-up of material from Diodorus, it worth stressing that Hobbes was very cognizant of the subversive, loyalty-altering power of classical texts, or more specifically of an education rooted in classical learning, as a particular part of the dialogue in the Behemoth makes clear. ${ }^{48}$

B. But how came the people to be so corrupted? And what kind of people were they that could so seduce them?

A. The seducers were of divers sorts... [1: Presbyterian ministers; 2: Papists; 3. Independents, Anabaptists, Fifth-monarchy-men, Quakers, Adamites, etc.] Fourthly, there were an exceeding great number of men of the better sort, that had been so educated, as that in their youth having read the books written by famous men of the ancient Grecian and Roman commonwealths concerning their polity and great actions; in which books the popular government was extolled by the glorious name of liberty, and monarchy disgraced by the name of tyranny; they became thereby in love with their forms of government. And out of these men were chosen the greatest part of the House of Commons, or if they were not the greatest part, yet, by advantage of their eloquence,

\footnotetext{
${ }^{48} \mathrm{Cf}$. the negative views on classical learning throughout Leviathan XLVI [367-380], particularly targeting the Scholastics and Aristotelianism.
} 
were always able to sway the rest... [5: London and other trade-towns; 6: warmongering opportunists; 7: the ignorant people themselves $].^{49}$

Here, Hobbes—or rather, Behemoth's didactic conversant “A," on the prompting of the student-figure "B"-refers to contemporary parliamentarians' educational exposure to a classical discourse that predominantly lauded popular liberty (republicanism) and anathematised monarchical rule. ${ }^{50}$ These parliamentarians are classed by Hobbes as one of the main categories of "seducers" away from loyalty towards the English monarchy, and thus as one of the principal causative forces behind the outbreak of the English Civil War. A certain intellectual susceptibility, perhaps a gullibility, is implied of this category, which is readily explicable when we consider the reflection adduced at the start of this paper:

Thucydides, in observing the travails and pitfalls of the governance of the Athenian state during its Peloponnesian War with Sparta, had long ago taught Hobbes how inepta-from ineptus, that is "foolish," even "absurd" or "senseless"-was the democratic system, and how preferable was monarchy. ${ }^{51}$

Evidently, Hobbes had positive and negative reflections on the power of classical texts to shape their readers. Classical learning could subvert away from the right path just as

${ }^{49}$ Hobbes, Behemoth, pp. 108-111 (I 2-4), with my own summaries in square-bracketed italics.

${ }^{50}$ Seaward, Thomas Hobbes: Behemoth, 24. More broadly, see the classic study of: Zera S. Fink, The Classical Republicans: An Essay in the Recovery of a Pattern of Thought in Seventeenth-Century England (Evanston, IL: Northwestern University Press, 1945).

${ }^{51}$ On Hobbes's “royalism," see: James J. Hamilton, "Hobbes the Royalist, Hobbes the Republican," History of Political Thought 30 (2009): 411-454. 
it can subvert towards it, the reader being the all-important factor: his or her interests, abilities, agendas, preoccupations, and more, not to mention individual determinations of what is normative and what is transgressive. Indeed, we shall see how in De homine and in Behemoth Hobbes engages with Diodorus' records of early, sometimes primeval humanity (as found in Bibliotheke $\mathrm{I}-\mathrm{V}$ ) in order to reflect subversively on his broader and contemporary intellectual historical context, examining some of the major institutional questions and debates of his day, particularly as relates to religion in the civil state and the role of the clergy in relation to the sovereign power. ${ }^{52}$ Here, it was not defunct, moribund, or hypothetical debates to which Hobbes was contributing with his readings of Diodorus, but rather-as we know was the case with his use of Thucydides too- - he was using such texts to articulate his self-positioning, intellectual and political, in relation to major issues in the modern day.

\subsection{Hobbes, Diodorus, and the Bible: theological subversion in De homine}

De homine, or "On Man," was published in 1658 as the third and final part of the Latin trilogy ("Elements of Philosophy") that included De cive ("On the Citizen," 1642) and De corpore ("On the body," 1655). This trilogy was intended to provide a tripartite, fundamental guide to Hobbes's philosophical system. Although De cive and to a lesser extent De corpore have received some measure of recognition in political theory, scholarly opinion on $D e$ homine has been less favourable, and indeed the work has never fully been translated into

\footnotetext{
${ }^{52}$ On Hobbes's subversiveness, and on (de)contextualising his work, see also: A.P. Martinich, "Hobbes’s Political-Philosophical Project: Science and Subversion,” in Interpreting Hobbes's Political Philosophy, ed. S.A. Lloyd (Cambridge: CUP, 2019), 29-49.
} 
English: ${ }^{53}$ of the total fifteen chapters, the first nine have been dismissed wholesale as “irrelevant to Hobbes's moral and political philosophy" by the only (partial) translators of $D e$ homine and so left untranslated. ${ }^{54}$ However, these sections contain treatments of cosmology and anthropology, and scientific debates such as human nutrition, uterine development, and death, all obviously ramifying for the larger discursive exploration of "man" that is the aim of the work, not to mention connecting with a range of widely embedded humanistic inquiries. Moreover, the long chapters 2-9 on optics are a surprisingly full, ${ }^{55}$ given the mid-seventeenth century context, treatise on the mechanics and phenomenology of vision, and the issues of visual cognition addressed there might have potential to offer epistemological ramifications for Hobbes's philosophy, and surely should figure into our understanding of his philosophical process in toto. ${ }^{56}$

${ }^{53}$ For the partial translation, of only chapters X-XV, see: Bernard Gert, ed., Thomas Hobbes: Man and Citizen (Indianapolis, IN: Hackett, 1991).

${ }^{54}$ Gert, Man and Citizen, 35.

${ }^{55}$ The chapters on optics seem to derive from earlier manuscripts that Hobbes had been working on (see: Noel Malcolm, Aspects of Hobbes (Oxford: Clarendon Press, 2002), 13, 18); this would accord with a note in the dedication to the work that the more difficult part of the work, namely the scientific, or the "physic-al," had long been in a state of readiness when eventually publication came.

${ }^{56}$ Cf. Stuart Clark, "Theology and the Conditions of Knowledge in the Seventeenth Century: The Case of Discernment of Spirits," in For the Sake of Learning: Essays in Honor of Anthony Grafton, vol. 1, ed. Ann Blair and Anja-Silvia Goeing (Leiden: Brill, 2016), 268285, esp. 275. 
It is in the very opening lines of this complex, neglected work that Hobbes makes explicit reference to Diodorus Siculus as the ultimate source of a longer debate on the origins of the human race.

On the origin of the human race there are two explanations frequently forwarded among the most ancient thinkers, as Diodorus Siculus, transcriber of ancient histories, attests. One of these holds that, because the world is eternal and has always stood, the race of man must have existed from eternity also. The other holds that the world came into existence at a definite point in time... which is not far off, though not precisely the same as, what is also transmitted in the first book of Genesis. ${ }^{57}$

Whatever the prevailing quotation culture was in Hobbes's time, ${ }^{58}$ this citational positioning - a direct act of naming in the opening sentence of a work - demonstrates Hobbes's high regard for Diodorus, and that he was his preferred classical authority on cosmogony and anthropogony in the context of the given work. ${ }^{59}$ In fact, the set-up of $D e$

${ }^{57}$ De homine I.1 = OL I.1 (excerpts, translation mine).

${ }^{58} \mathrm{Cf}$. Francis Bacon's condemnation of encycopaedism and citation of ancient authors, discussed at: Marjorie Swann, Curiosities and Texts: The Culture of Collecting in Early Modern England (Philadelphia, PA: University of Pennsylvania Press, 2001), 59.

${ }^{59}$ Hobbes's use of Diodorus here has been noted by several scholars, though none of these dwell on the larger implications. See inter alia: Kraynak, History and Modernity, 23 n.15; Springborg, "Hobbes... and the Historia Ecclesiastica", 553-571; Patricia Springborg, "Hobbes on Religion," in The Cambridge Companion to Hobbes, ed. Tom Sorell (Cambridge: CUP, 1996), 346-380, esp. 368; Seaward, Thomas Hobbes: Behemoth, 28. 
homine is largely the same as in Diodorus' own work: ${ }^{60}$ two opposing views on the existence of the universe, one eternalist and one creationist, are presented as having currency in past and present, though only the creationist account is elaborated in detail, with the eternalist view minimised to mere summary. We might also compare here Diodorus' use in a similar context in the De Inventoribus Rerum of Polydore Vergil (abridged and translated into English by Thomas Langley in 1546) ${ }^{61}$ and the Troia Britanica of Thomas Heywood (1609): ${ }^{62}$ Hobbes was clearly not the first in England to frame debates on human and cosmic origins with reference to Diodorean testimony.

In this light, Hobbes's comparison of the creationist view reported by Diodorus with that found in the book of Genesis is significant, inasmuch as he fields both classical and biblical testimony to support a forthcoming opposition to Scholastic Aristotelian theology. He

${ }^{60}$ See: Diodorus Siculus I.6-8, esp. I.6.3: “Concerning the first origin of humanity, therefore, two judgements have arisen among the most expert figures in the fields of natural sciences and history..." (all translations of Diodorus are my own).

${ }^{61}$ On Polydore Vergil's use of Diodorus Siculus, see: Brian P. Copenhaver, "The Historiography of Discovery in the Renaissance: The Sources and Composition of Polydore Vergil's De Inventoribus Rerum, I-III," Journal of the Warburg and Cortauld Institutes 41 (1978): 192-214; Catherine Atkinson, Inventing Inventors in Renaissance Europe (Tübingen: Mohr Siebeck, 2007), 106-108. Langley's translation/abridgement at I.3 is very similar to Hobbes's phrasing at De homine I.1: “The most famous writers of natural Histories (as Diodorus recordeth) spake of two sundry manners of birth, and first stock of mankind." ${ }^{62}$ Canto 1 of Troia Britanica is again highly reminiscent of De homine I.1: "Nor hath it beene Eternall (as is thought / By naturall men) that haue no further sought. / Neither hath man in perpetuity bin, / And shall on earth eternally perseuer...” 
does not, however, try to draw total equation between these two testimonies, since there is a major discrepancy: there is no Creator-figure in Diodorus' account, no causative intelligence, but rather an almost spontaneous generation of the cosmos - on which grounds, incidentally, the fourth-century bishop Eusebius of Caesarea criticises Diodorus' cosmogony. ${ }^{63}$ In other words, Hobbes does not oppose the eternity of the universe by framing an appeal to the authority of Genesis alone, or to the Bible as an insuperable historical record - in Hobbes's view, this was a text written by man, however inspired by $\operatorname{god}^{64}$-nor does he advocate a return to scriptural literalism, given his own penchant for subtle, learned exegesis. ${ }^{65}$ Instead, we see an interconnected, coordinated mode of referentiality, with reference to one sacred historical source, namely the Bible, alongside one profane historical source, namely Diodorus' Bibliotheke. ${ }^{66}$ We will see this model again, and for now it is worth noting that

${ }^{63}$ Eusebius Praeparatio Evangelica I.7.16.

${ }^{64}$ See inter alia: Anna Lisa Schino, "Hobbes and Sacred History: Two Political Covenants and a Covenant for Salvation," Cultural and Religious Studies 5 (2017): 452-464. For a longer articulation of Hobbes's views on the authorship of the scriptures, see Leviathan XXXIII [199-206]. Cf. Leviathan VII [32].

${ }^{65}$ On Hobbes's biblical exegesis, see inter alia: Arrigo Pacchi, "Hobbes and Biblical Philology in Service of the State," Topoi 7 (1988): 231-239; Noel Malcolm, “The Name And Nature of Leviathan: Political Symbolism and Biblical Exegesis," Intellectual History Review 17 (2007): 29-58; Jeffrey L. Morrow, "Leviathan and the Swallowing of Scripture: The Politics behind Thomas Hobbes's Early Modern Biblical Criticism," Christianity and Literature 61 (2011): 33-54.

${ }^{66}$ On Hobbes and sacred history, see: Karl Schuhmann, "Hobbes’s concept of history,” in Hobbes and History, ed. G.A.J. Rogers and Tom Sorell (London: Routledge, 2000), 16-17; 
this convergent substantiation firstly reaffirms Hobbes's appreciation of the value of Diodorus' work, and secondly points specifically to an editorial mode of interaction with it, which sought to excavate viable examples and arguments from Diodorus' work to bolster his own argumentative agendas. ${ }^{67}$

After his cosmology, Diodorus provides an extended anthropology, an account of man's progress from earliest origins to civilised society. ${ }^{68}$ Parts of De homine seem to show a clear alignment with this anthropology. The tenth chapter of De homine, for instance, stresses

Franck Lessay, "Hobbes and Sacred History," in Hobbes and History, ed. G.A.J. Rogers and Tom Sorell (London: Routledge, 2000), 146-158.

${ }^{67}$ Cf. Alison McQueen, “'A Rhapsody of Heresies': The Scriptural Politics of On the Citizen," in Hobbes's On the Citizen: A Critical Guide, ed. Robin Douglass and Johan Olsthoorn (Cambridge: CUP, 2019), 180-198, esp. 189-90, which argues in part that Hobbes used "convergent" argumentation (more than one argument at the same time) in a forensiclike fashion to make his points in De Cive; McQueen also makes the broader point that Hobbes engages quite closely with scriptural evidence, particularly relating to the early Israelite kingdom, to support his points about contemporary English politics and religion. The convergent substantiation that I discuss here might relate to this phenomenon of convergent argumentation quite closely, and the use of early Israelite history (as told by the Old Testament) is similar to invocations of other early near eastern kingdoms elsewhere in Hobbes's oeuvre - not least Behemoth, as we shall see in the next section.

${ }^{68}$ Diodorus' anthropology: I.8.1-9. Some important modern discussions include: Charles H. Kahn, Anaximander and the Origins of Greek Cosmology (Indianapolis, IN: Hackett, 1960), 110-113; Thomas Cole, Democritus and the Sources of Greek Anthropology (Chapel Hill, NC: APA, 1967); Muntz, Diodorus and the Late Roman Republic, 57-88. 
the importance of the distinction between the civilised man and the natural man, the latter being in effect indistinguishable from wild beasts. Hobbes's distinction here is quite strongly redolent of Diodorus, who among other points argues that early man "subsisted in a

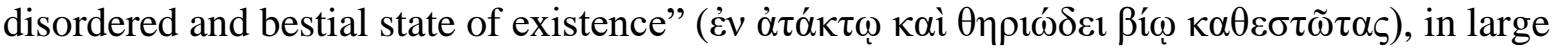
part because of his lone (rather than collective) efforts to overcome the state of nature. ${ }^{69}$ Unlike many other anthropological narratives from antiquity, there is no primordial "Golden Age" in Diodorus, but rather a primitive, harsh beginning for humanity, who slowly progressed, with great toil, on a trial and error basis, towards a "civilised" state. ${ }^{70}$ Here we can also point to Hobbes's speculation on the origins of speech and language, and to how he exposits the importance of speech as being a distinction unique to man — specifically, mankind's unique intellectus — his "rational understanding"—of how words constitute significatio ("signification"). ${ }^{71}$ For Hobbes, speech-uptake is a crucial basis for all of society's structures, and in fact "without this there would be no society among men, no peace, and consequently no disciplines; but first savagery, then solitude, and for dwellings, caves."72

${ }^{69}$ Diodorus Siculus I.8.1.

${ }^{70}$ On ancient Greek and Roman anthropologies, see inter alia: Cole, Democritus and... Greek Anthropology; Jenny Strauss Clay, Hesiod's Cosmos (Cambridge: CUP, 2003), 81-99; Muntz, Diodorus and the Late Roman Republic, 57-88; David Konstan, “Mankind's Past: Evolution or Progress?," in Imagines Antiquitatis: Representations, Concepts, Receptions of the Past in Roman Antiquity and the Early Italian Renaissance, ed. Stefano Rocchi and Cecilia Mussini (Berlin: De Gruyter, 2017), 17-26.

${ }^{71}$ De Homine 10.1 = Gert, Man and Citizen 37-38. This reflection has much in common with the account in Leviathan IV [12-17].

${ }^{72}$ De homine 10.3 = Gert, Man and Citizen 39-40. 
Again, this shows a potential correspondence with Diodorean anthropology, specifically how speech- and language-acquisition constitute an evolutionary milestone for humanityalthough in Diodorus we see more emphasis on the social, collectivist development of language, not just on an innate faculty or disposition for such. ${ }^{73}$ Additionally, towards the end of his anthropological account, Diodorus articulates that man is effectively sui generis with respect to his concerted physical, vocal, and intellectual capacity: here we perhaps see early shades of the notion of "man as a uniquely rational creature," and certainly Hobbes's views on humanity chime with this. ${ }^{74}$ One could even connect the wretched state of early man in Diodorus with Hobbes's more famous picture of such in Leviathan, ${ }^{75}$ which would suggest that Hobbes had deeper connection with Diodorean thought than has been previously determined. ${ }^{76}$

${ }^{73}$ On the narrative of language-development in Diodorus, see inter alia: Cole, Democritus and... Greek Anthropology, 60-1, 63-7, 79, 108-9; Alexander Verlinsky, "Epicurus and his predecessors on the origin of language," in Language and Learning: Philosophy of Language in the Hellenistic Age, ed. Dorothea Frede and Brad Inwood (Cambridge: CUP, 2005), 60-63; Muntz, Diodorus and the Late Roman Republic, 60, 61, 65- 66, 75, 77, 121- 122.

${ }^{74}$ See Leviathan V [18-22] on man's ability to reason.

${ }^{75}$ Leviathan XIII [60-63]. For the potential link, on the issue of primitive early humanity, between Hobbes on the one hand and Lucretius and Diodorus Siculus on the other, see: Kinch Hoekstra, "Hobbes on the natural condition of mankind," in The Cambridge Companion to Hobbes 's Leviathan, ed. Patricia Springborg (Cambridge: CUP, 2007), 109-127.

${ }^{76}$ One might also suggest that Diodorus' presentation of cosmogony is behind Hobbes's relation of the same in Leviathan XII [52-60]. 
There remains much more to say in the future about De homine and its position in various intellectual-historical currents. On the basis of the brief discussion so far, there are good grounds for positing a relationship between parts of De homine and the cosmological and anthropological narratives found in book one of Diodorus, and even here there remains more material than can viably be covered with full diligence at present. One point that deserves extended attention, however, is a puzzle in De homine's dedicatory epistle, written by Hobbes to his patron William Cavendish.

The first part of this section was long since ready for the press. 'Why, then,' you may ask, 'since the remainder was easy, have we had to await publication so long? What have you been doing in the meantime?' I reply, 'I have been fighting the beasts ( $\dot{\varepsilon} \theta \eta \rho 10 \mu \alpha ́ \chi \eta \sigma \alpha)$.' For I too have my Demetriuses and Alexanders, whose trifling

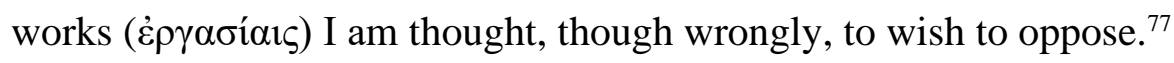

Here, when imagining challengers to his work on the basis of the long delay in the completion of the Elements trilogy (De cive began the trilogy sixteen years before, in 1642), Hobbes asserts that he would respond simply: $\dot{\varepsilon} \theta \eta \rho ı \mu \alpha ́ \chi \eta \sigma \alpha$, ethēriomachēsa, i.e. "I fought with wild beasts." The Greek verb (aorist tense, from thêriomacheō) is quite rare, though it has a clearly explicable meaning from the compound of the noun "beast" (therrion) and the

${ }^{77}$ This has been translated, along with chapters 10-15 of De homine, at: Gert, Man and Citizen, 35-36. The Latin from the preface of OL II: Diu est quod pars prior typis parata erat. Cur ergo, inquies, cum reliqua facillima erat, tam diu editionem expectavimus? Quid interea

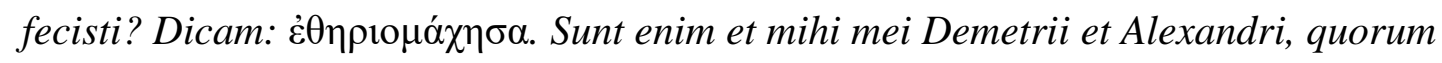
Ėpyaбíaı obstare velle falso existimatus sum. 
verb "fight" (machomai). Additional philological digging offers a greater insight into Hobbes's intended meaning here.

On one level, it seems that Hobbes is making a reference to the New Testament. In chapter XV of his first epistle to the Corinthians, Paul, in seeking to reinforce a point of interpretation regarding Christian eschatology, asks the Corinthians: "If after the manner of men I have fought with beasts at Ephesus (ethēriomachēsa), what advantageth it me?"78 This seems to be a secure intertextual reference, since Hobbes, like Paul before him, describes himself as having fought with wild beasts using exactly the same conjugation of the verb thēriomacheō. What underpins this intertext as a meaningful choice for Hobbes is its source context in Corinthians. Although sometimes interpreted literally, ethēriomachēsa is here surely meant metaphorically instead, as referring to Paul's teaching of the gospel to the pagans of Ephesus, and to his struggle to keep the early Christians there on the right path. ${ }^{79}$ So ethêriomachēsa is used by Paul to signify the intellectual challenges he faced in trying to proselytise among the peoples of Asia Minor: in bare terms, the wild animals of the metaphor are those pagans that resist, dissent from, reject, oppose his message and his teachings.

Hobbes's choice of a form of theriomacheō to articulate the delay to De homine's publication and the completion of the Elementa trilogy is a striking act of self-comparison. However tongue-in-cheek the reference might be, he still implicitly casts himself as an apostolic illuminator of doctrinal truth amid a sea of heretical opponents. New Testament scholars have suggested that Paul was the first ever to use that specific compound word

\footnotetext{
${ }^{78} \mathrm{KJV}$ translation.
}

${ }^{79}$ See the discussion of interpretative possibilities at: Daniel Frayer-Griggs, "The Beasts at Ephesus and the Cult of Artemis," Harvard Theological Review 106 (2013): 459-477, esp. 460-3. 
therriomacheō, while others have suggested it is a hapax legomenon (a unique word, not repeated in any other text). ${ }^{80}$ In fact, there is one- only one- earlier usage, to be found in the third book of Diodorus' Bibliotheke ${ }^{81}$ Here, Diodorus is describing an unlocatable part of the Arabian peninsula, which he characterises in idyllic, naturalistic, almost primeval terms: it is alluvial, abundant in pasturage, replete with non-predatory flocks and herds, a veritable paradise. Yet, it is also continually beset "from the desert" by wild beasts, and to protect the peaceable flocks and herds the herdsmen dwelling there must $\dot{\eta} \mu \varepsilon \dot{\rho} \alpha \nu \kappa \alpha i ̀ ~ v v ́ \kappa \tau \omega \rho$ $\theta \eta \rho 10 \mu \alpha \chi \varepsilon \tilde{v}$, "fight with wild beasts by day and by night." This is a passage that lends itself to metaphorical readings — order against chaos, civilisation against barbarism, a settled community against an invading force — that link back to Diodorus' account of the evolutionary development of earliest mankind, namely the recognition that collectivismliving together in communities — was an expedient for defence against thēria, wild beasts. The motif of herdsmen protecting pacific flocks against marauding wild beasts has a potential political dimension, too- particularly as relates to monarchy, but not exclusively. ${ }^{82}$ There are multiple levels of appeal here for a later Christian interpreter, not least Paul, and a clear basis for relocating thèriomacheō to a more specialised realm of semantic significance, of Christian truth versus pagan heresy - a natural refinement of, yet coexistent with, the fundamental

${ }^{80}$ For a survey of interpretations and possible meanings, and the designation of the riomacheo as a hapax, see: Frayer-Griggs, "The Beasts at Ephesus," 459-477, esp. 460-3.

${ }^{81}$ Diodorus III.43.6-7.

${ }^{82}$ See e.g. the "shepherd of the people" metaphor, fairly common in Greek political imagery from Homer onwards: Roger Brock, Greek Political Imagery from Homer to Aristotle (London: Bloomsbury, 2013), 43-52. 
sense of order versus chaos, and civilisation versus barbarism, that inheres in the Diodorean exemplar.

There is an additional, complementary detail that coheres with this discourse in $D e$ homine's dedication. Immediately after writing that the work's publication was delayed because he fought with wild beasts (ethēriomachēsa), Hobbes writes: "For I too have my

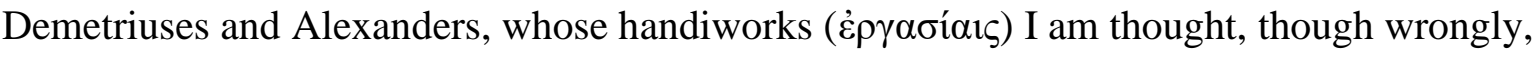
to wish to oppose." ${ }^{83}$ This is another puzzle to be unlocked through tracing the allusions (Demetrius, Alexander, ergasiai), which can be done fairly securely once the reference in Corinthians to Paul's ministry in Ephesus is understood. We can identify Alexander and particularly the silversmith Demetrius as opponents to Paul in Ephesus, as recorded in Acts XIX. ${ }^{84}$ The livelihood of Demetrius was dependent on the fashioning of certain ergasiai, "handiworks" that were miniature silver models of the famous temple of Artemis in Ephesus, and he was involved in inciting major civic riots against Paul's ministry. Demetrius sloganeered under the name of the great Ephesian goddess Artemis and persuaded his fellow craftsmen that Paul, in speaking against idolatry, was threatening the guild's or association's profitable silver-craft as fashioners of ergasiai. $^{85}$ Just as Paul himself is Hobbes's selfasserted analogue, these Ephesian opponents of Paul become akin to Hobbes's own intellectual opponents in the present day: Hobbes is the reformist on the true path, his

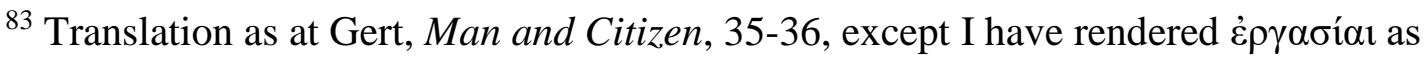
"handiworks" ("professional works" would also work) instead their choice of "trifling works.”

${ }^{84}$ See Acts XIX 22-41.

${ }^{85}$ In general, see: Robert F. Stoops, Jr., "Riot and Assembly: The Social Context of Acts 19:23-41,”Journal of Biblical Literature 108 (1989): 73-91. 
adversaries are traditionalists clinging to old ways in the face of theological and social progress. By extension, the delay in De homine's publication becomes akin to the setback of the early Christian gospel that occurred as a result of the Ephesian riots, instigated by hawkers of idolatrous bric-a-brac looking to protect their profit and their social positions.

Taken as a whole, this is a remarkable dedicatory sentiment in terms of message, not to mention sophisticated in terms of its allusive literary character. We can see here Hobbes's exegetism, inasmuch as he clearly interprets Paul's claim to have fought with beasts (as recorded in the epistle to the Corinthians) as referring to his opposition from the silversmiths (as recorded in Acts XIX) — an interpretation at which some later commentators have also arrived. ${ }^{86}$ As a well-attested admirer of Paul, ${ }^{87}$ and indeed highly individualistic exegete of biblical texts, Hobbes's sophisticated understanding of a biblical model here is perhaps no great surprise, and it is in keeping with his subtle exegesis that we can see so often instance in Leviathan ${ }^{88}$ However, the boldness and the distinctiveness of this dedication, and its particular pertinence for this discussion, inheres rather in the intellectual-historical implications of his self-comparison to early apostles among the pagans, especially in terms of how it recasts the subversive, deliberately oppositional nature of Hobbes's philosophical views as an authentic gospel-truth in a world of doctrinal idolatry and epistemological

\footnotetext{
${ }^{86}$ See: Frayer-Griggs, "Beasts at Ephesus," 459-477, for the particularly persuasive suggestion that the association with the goddess Artemis, mistress of wild beasts, informed Paul's characterisation of Demetrius et al. as beasts with whom he had fought.

${ }^{87}$ Pacchi, "Hobbes and Biblical Philology," 234.

${ }^{88}$ See n.65, above.
} 
waywardness. As a lone voice of wisdom, Hobbes's philosophy distinguishes him from the beasts, his civilisation standing out among, and under assault by, their barbarism. ${ }^{89}$

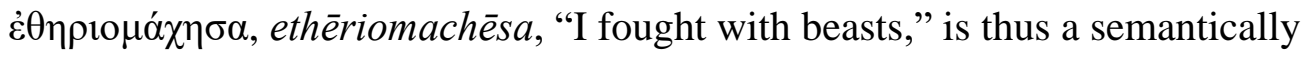
expansive intertextual reference that gives orthodoxy to Hobbes's philosophical position while traducing those of his rivals; in effect it celebrates and eulogises his own subversiveness. It is also a singularly apposite word to use in the context of a work that is so heavily grounded in Diodorean source material and anthropological discourse-overcoming wild beasts as a pivotal step in the evolution and civilisation of the human race, for instance - not to mention De homine's stress on the significatory power of words and the distinction of intellectus, of understanding such signification, as separating men from beasts. Perhaps, specifically, this relates to Hobbes's broader agenda of subverting the Scholastic intellectual and theological stranglehold of education,,$^{90}$ though a precise analogue for Hobbes's opposition is not necessarily of primary importance here as it could be interpreted and applied flexibly. Here it should be stressed, against the trend of seeing an atheistic Hobbes, that Hobbes seems to want to reform religion rather than to disavow it. ${ }^{91}$ At any rate,

${ }^{89}$ Cf. Hobbes's own anticipation of De homine's publication, writing that "though by the contumelies and petty injuries of some unskillful men, I know already, by experience, how much greater thanks will be due than paid me, for telling the truth of what men are." For full reference, and more on Hobbes's views of the potential impacts of his own work, see: Christopher Scott McClure, Hobbes and the Artifice of Eternity (Cambridge: CUP, 2016), 45. ${ }^{90}$ See, famously, Leviathan XLVI [370].

${ }^{91}$ On the question of Hobbes as atheist, see inter alia: Willis B. Glover, "God and Thomas Hobbes,” Church History 29 (1960): 275-297; Thomas L. Pangle, “A Critique of Hobbes's 
the intertextual reference is also apt in terms of how it mirrors the referential mode already seen in De homine, the use of a convergent model of referentiality, simultaneously evoking biblical scripture on the one hand and Diodorus' Bibliotheke on the other. This is a multireferential pastiche, a deployment of several different ideas and intellectual currents in deliberate juxtaposition, though in service of a clear aim: subverting and downgrading existing wisdom while also offering an evidence-based, progressive set of alternatives. ${ }^{92}$

\subsection{Hobbes, Diodorus, and civil war: political subversion in Behemoth}

While there are, as discussed, a number of direct references to Diodorus across Hobbes's works, arguably the most sustained constellation of citations and quotations comes from Behemoth (or, to give its full title, Behemoth: The history of the causes of the civil wars of England, and of counsels and artifices by which they were carried on from 1640 to the year 1660). It is also in Behemoth, probably not coincidentally, that we see a subversive agenda animating the use of a framework of exempla drawn from Diodorus, and indeed it is the same parts of Diodorus - the first pentad of books, covering early human societies prior to Greece and Rome - that constitute Hobbes's primary reading of Diodorus. Here, however, as we shall see, it is a primarily political rather than theological subversion that Hobbes deploys.

Critique of Biblical and Natural Religion in 'Leviathan'," Jewish Political Studies Review 4 (1992): 25-57; Martinich, “Hobbes’s Political-Philosophical Project,” 29-49, esp. 30-33.

${ }^{92}$ Cf. Springborg's view on opening of Hobbes's Historia Ecclesiastica, perhaps a comparable pastiche: "Hobbes's Historia Ecclesiastica...," 95: “Although the theogony with which Hobbes begins his poem is clearly taken from Diodorus Siculus, it parodies Hesiod's own Theogony, its story of the creation of the world, and genealogies of the gods and heroes from the pagan cosmologies." 
Behemoth, perhaps composed in the late $1660 \mathrm{~s},{ }^{93}$ is a work that treats the English Civil War from its origins to its aftermath, across the breakdown of loyalty to the monarchy, the rise of Cromwell and execution of Charles I, the protectorate of Cromwell, and the restoration of the Stuart dynastic line in the person of Charles II. The work is framed as a dialogue between two speakers-simply called A and B, one the teacher and the other the student — and in a number of respects it looks like a didactic Socratic dialogue. ${ }^{94}$ This is perhaps a more natural thinking-ground for Hobbes's view on absolutist sovereignty, ${ }^{95}$ and it is also tempting see this in terms of escaping an Aristotelian categorisational model, and hence as part of his opposition to the Scholastics — which reaches a high water-mark in Behemoth, such as when he calls two leading Scholastics, Peter Lombard and John Scot of Duns, "two of the most egregious blockheads in the world, so obscure and senslesse are their writings." 96

In an important section of the work, in the Second Dialogue, we see the didactic speaker A respond to student B's request that he prove, giving names of "Authors and Places," his own claim that

Philosophy together with Divinity have conduced to the advancement of the Professors thereof, to places of greatest honour and authority, next to the authority of Kings

${ }^{93}$ See n.21, above.

${ }^{94}$ On the dialogic Socratic methods, see e.g.: Kenneth Seeskin, Dialogue and Discovery: A

Study in Socratic Method (Albany: SUNY Press, 1987), esp. 1-54.

${ }^{95}$ Cf. Patricia Springborg, "Thomas Hobbes and Cardinal Bellarmine: Leviathan and the Ghost of the Roman Empire," History of Political Thought 16 (1995): 503-4.

${ }^{96}$ Hobbes, Behemoth, p. 160 (I.20). 
themselves, in most of the ancient Kingdoms of the world, as is manifestly to be seen in the history of those times. ${ }^{97}$

Here, to answer B's request, Hobbes turns principally to Diodorus Siculus, and to a lesser degree to what must be common biblical knowledge, ${ }^{98}$ as his main authority, and gives seven examples of such eminent "philosophers" (that is, priests) among ancient monarchic societies. He quotes, probably in his own translation, extended passages of Diodorus' text relating stories about the Druids of Brittany and France, the Magi of Persia, the priestly class of Egypt, the Levite Jewish priesthood, the Chaldeans of Assyria, the philosophers of India, and the priests of Ethiopia. ${ }^{99}$

\begin{tabular}{|l|l|l|}
\hline Topic in Behemoth & $\begin{array}{l}\text { Correspondence with } \\
\text { Diodorus' Bibliotheke }\end{array}$ & Other notes \\
\hline Druids of Brittany and France & V 31, direct quotation & \\
\hline Magi of Persia & n/a & Biblical knowledge $(N T)$ \\
& assumed. NB. birth of Christ \\
& postdates Diodorus \\
\hline Priests of Egypt & I 73.2, 75.3-5, direct & \\
& quotations & \\
\hline
\end{tabular}

${ }^{97}$ Hobbes, Behemoth, p. 226 (II.43).

${ }^{98}$ Cf. Robert Kraynak, "The fragility of civilization in Hobbes's historical writings,"

Filozofski vestnik 24 (2003): 37-58, esp. 44.

${ }^{99}$ Hobbes, Behemoth, pp. 225-231 (II.43-46). 


\begin{tabular}{|c|c|c|}
\hline Levite Jewish priesthood & $\mathrm{n} / \mathrm{a}$ & $\begin{array}{l}\text { Biblical knowledge }(O T) \\
\text { assumed }\end{array}$ \\
\hline Chaldeans of Assyria & $\begin{array}{l}\text { II 29.2-4, direct } \\
\text { quotation }\end{array}$ & \\
\hline Philosophers of India & $\begin{array}{l}\text { II 40.1-3, direct } \\
\text { quotation }\end{array}$ & \\
\hline Priests of Ethiopia & III 5-6, direct quotation & \\
\hline
\end{tabular}

Fig. 1: Correspondences between the Second Dialogue of Hobbes's Behemoth and Diodorus Siculus' Bibliotheke Historike.

Effectively the same list, though more telegraphically expressed, is also found in the earlier work Leviathan, with the same emphasis: priests and philosophers of early monarchic societies, referring to India, Persia, Chaldea, and Egypt. ${ }^{100}$ No "source" is adduced by Hobbes here, but presumably it is Diodorus, indicating a long reflection on the passages in question. $^{101}$

As the introductory framing of the proofs suggests, the aim of this supplying of evidence is to prove the argument that priests and other religious officials have found ways to ascend to high authority — and, especially, high influence with respect to monarchic

${ }^{100}$ Leviathan XLVI [368].

${ }^{101}$ Cf. Springborg, "Hobbes’s Historia Ecclesiastica...," 140-1, on reference to these societies also in the Historia Ecclesiastica: the "collar of truth" story, drawn from Diodorus' account of Egyptian judiciary, is particularly prominent. See also: Somerville, "Hobbes, Behemoth... and Political Obligation," 205-222; Seaward, Thomas Hobbes: Behemoth, 2829. 
institutions - in all world history, with an implicit parallel drawn between those of ancient times and those of contemporary, early modern England. There is an anti-ecclesiastical, anticlerical animus throughout all of these examples, which connects not just with Hobbes's broader attitudes towards the Scholastics, discussed above, but also with the historical topic of Behemoth, namely the English Civil War. Most strikingly, Hobbes's last Diodorean example of an early society with heavy theocratic influence is Ethiopia, and according to this chosen account the Ethiopian king, Ergamenes, broke the power of the priesthood by killing all the priests, abolishing their traditional right of determining the monarch's longevity and, thereafter, organising his kingdom according to his own will. A, the teacher, then speculates that if Charles I had taken this course of action, it might have been for the better, saying that "Had it not been much better that those seditious Ministers, which were not perhaps a thousand, had been all killed before they had preached. It had been (I confesse) a great Massacre, but the killing of a hundred thousand is a greater." 102 Although perhaps not in the way Diodorus might have intended, Hobbes's teacher here heeds the didactic purpose of the Bibliotheke and uses its historical exempla to reflect on contemporary problems.

The general purpose of the long series of quotations of Diodorus is then spelled out explicitly by A:

I intend not by these quotations to commend either the divinity or the philosophy of those heathen people; but to show only what the reputation of those sciences can effect among the people. For their divinity was nothing but idolatry; and their philosophy (excepting the knowledge which the Egyptian priests, and from them the Chaldeans, had gotten by long observation and study in astronomy, geometry, and arithmetic), very little;

${ }^{102}$ Hobbes, Behemoth, p. 231 (II.46). 
and that in great part abused in astrology and fortune-telling. Whereas the divinity of the clergy in this nation, considered apart from the mixture (that has been introduced by the Church of Rome, and in part retained here) of the babbling philosophy of Aristotle and other Greeks, that has no affinity with religion, and serves only to breed disaffection, dissension, and finally sedition and civil war (as we have lately found by dear experience in the differences between the Presbyterians and Episcopals), is the true religion.

We immediately see links with the ideas found in De homine. Alternative philosophical-cumtheological systems are idolatrous, recalling the implication in De homine's dedication of Hobbes's intellectual true faith in contrast the idolatrous ergasiai, "handiworks," of his opponents. ${ }^{103}$ These shows examples of what might be called, in relation to Hobbes's day, "priestcraft." 104 We see again Hobbes's anti-Scholastic position, though here the latter-day Aristotelians are implicitly paralleled with the priests and philosophers of early, heathen societies, enjoying a position of power according to their reputation or image of learning, not any substantive true understanding: perhaps for Hobbes, the Scholastics are the new pagans, and modern-day priests are as bad as the power-grabbing idolaters of antique societies. The references to various embedded theocratic hierarchies from Diodorus' Bibliotheke, then,

${ }^{103}$ It seems that ergasia does carry the specialised sense of (profit-driven) idolatry in the Bible, and not necessarily a tangible object, judging by e.g. Acts XVI 16-19, where it refers to $\pi v \varepsilon \tilde{u} \mu \alpha$ Пv́$\theta \omega v o \varsigma$ (“a spirit of divination”).

${ }^{104}$ On priestcraft, see primarily: J.A.I. Champion, The Pillars of Priestcraft Shaken: The Church of England and Its Enemies, 1660-1730 (Cambridge: CUP, 1992). See also: James A.T. Lancaster, "From matters of faith to matters of fact: the problem of priestcraft in early modern England," Intellectual History Review 28 (2018): 145-165. 
serve the aim of illustrating the importance of the issue of proper theological and philosophical education, just as they do the aim of reflecting on the impropriety in a monarchic society of the deep advancement of priestly power into the sovereign estate. Indeed, it is clear that these societies referred to by Hobbes via Diodorus are to be seen as the earliest known examples of civil religions in world history, ${ }^{105}$ so Hobbes is effectively demonstrating the character of priesthoods ab initio.

\section{The antiquary and the philosopher: conclusions}

It is clear that the first few books of Diodorus' Bibliotheke, those which deal with early human societies prior to the rise of Greece and Rome, played an important role in both $D e$ homine and Behemoth. In the former, his work serves as an anthropological and cosmological model, which is invoked alongside biblical testimony, and it seems likely that the Diodorean ideas informed Hobbes's own views about early man; at the very least, there is clear coherence and convergence between the two. In the latter, Diodorus' collections of stories about early theocratic elites in monarchic societies serve as proof in support the Hobbesian critique of the entanglement of philosophy and divinity in his own era. In each case, it is apparent that Hobbes valued Diodorus' work very highly - and it is in the context of recording indebtedness in the Behemoth that Hobbes calls Diodorus "the greatest antiquary perhaps that ever was."

As discussed in the introduction, this valuation of Diodorus sits along a high valuation of Thucydides. The modern dissonance occasioned by a critical appreciation of both Diodorus and Thucydides — who has fared considerably better in modern times — is clearly

\footnotetext{
${ }^{105}$ Cf. Springborg, "Hobbes's Historia Ecclesiastica...," 140-1, on reference to these also in the Historia Ecclesiastica.
} 
not one that was felt in Hobbes's own seventeenth-century context. Indeed, we can see some cases in which Hobbes seemingly prefers Diodorus over Thucydides, such as in his anthropological accounts of early humanity. Here, even though Thucydides' archaiologia may well have been an influence in general terms, it remains true that a better analogue for Hobbes's assessment of the early human condition-most famously elaborated in the Leviathan, a section which includes the famous description of "poor, nasty, brutish, and short," though it is to be found detailed in works such as De homine too, as we have seen-is Diodorus' own anthropology. ${ }^{106}$

Kraynak suggests that Hobbes esteemed Diodorus so highly because he admired the attempt to write a universal history and because many of Diodorus' themes (in the earlier books) - myths of creations, early societies, cultural progress from barbarism to civilisation, divinity and priesthoods - are picked up by Hobbes himself. ${ }^{107}$ In other words, perhaps Hobbes responded to Diodorus' work so positively because he saw its exemplarity and the potential transferability of its messages to his own context, both socio-political and intellectual-historical. This fits well in the contemporary humanistic culture, and educational system, which prioritised in the reading of history digestible sententiae which could effect

${ }^{106}$ Cf. Tim Rood, "The Reception of Thucydides' Archaeology," in A Handbook to the Reception of Thucydides, ed. Christine Lee and Neville Morley (Oxford: Wiley-Blackwell, 2015), 489: "like the Enlightenment philosophers, [Hobbes] had other ancient sources: the idea of early human life as brutish, for instance, is found in Lucretius and Diodorus (a writer Hobbes admired) but not in Thucydides." Diodorus (alongside Lucretius) is well-noted as a possible source for early modern anthropology in Rubiés, "Ethnography, philosophy and the rise of natural man," 97-127.

${ }^{107}$ Kraynak, History and Modernity, 19, with n.14 
personal improvement rather than promote reflection on historical complexity. ${ }^{108}$ It also fits well with "the marriage... of humanist research into the pagan religions with a Protestant ecclesiological position" that so characterised Hobbes's works and those of many of his contemporaries. ${ }^{109}$ In this respect, Hobbes is to be placed in a much longer Christian tradition of reading Diodorus, including writers and theologians such as Eusebius, Justin Martyr, Julius Africanus, and John Malalas. ${ }^{110}$ Similarly, in Byzantine circles, Kaldellis suggests that Diodorus' first pentad in particular was popular because these books provided "a clearly written, anecdotal, and lightly moralizing survey of the mythical prehistory of the major peoples of the ancient world that did not presuppose the truth of pagan religions claims... and were a "friendly" pagan companion to ancient debates about cultural priority and religious truth." ${ }^{111} \mathrm{He}$ also suggests that these five books offered a range of material for Christian polemic. In short, there was much in Diodorus that could be marshalled in service of Hobbes's aims, and there is much in the tradition of reading and utilising Diodorus prior to Hobbes that illuminates this usage- - just as it also casts a light on longer-term perceptions of Diodorus' work over centuries of reception.

There are perhaps further reasons as to why Hobbes was interested in Diodorus' Bibliotheke, and most particularly in the first five books narrating early human societies. Just as Thucydides was valued by Hobbes for (among many other things) what he saw as his antidemocratic attitude, and the lessons that such generated for intellectually shoring up the theory behind the monarchic form of government, so too Diodorus was valued for his wealth

\footnotetext{
108 Timothy Raylor, Philosophy, Rhetoric, and Thomas Hobbes, 65-66.

${ }^{109}$ Quotation from: Collins, Allegiance of Thomas Hobbes, 51.

${ }^{110}$ See: Monfasani, "Diodorus Siculus," 65-66.

${ }^{111}$ Kaldellis, Byzantine Readings of Ancient Historians, 80-1.
} 
of information on ancient monarchies in practice-more particularly, information on ancient monarchies which were not characterised by a Greek and Roman tradition of freedom and popular liberty, information which Hobbes could use as positive and negative didactic exempla, to his own intellectual ends. Indeed, Diodorus, "the greatest antiquary perhaps that ever was," was not in Hobbes's eyes straightforwardly the "historian" that Thucydides was; quite rightly, Hobbes seems to have regarded Diodorus as preserver of a different kind from Thucydides' model, but whose work had its own value when assessed in its own terms, not by the yardstick of model that was entirely dislocated from it. Indeed, the dissonance between readings of Diodorus in early and more recent modernity presents an opportunity for reestablishing Diodorus' significance in the classical tradition in future, not least in the corpus of Hobbes's works, among which more research needs to be undertaken to ascertain the extent of Diodorus' intellectual reach. 